\title{
NAJSTARIJI PISANI TURSKI SPOMENICI
}

Orhonski natpisi su najstariji pisani izvori o Turcima, njihovoj prvoj naseobini u slivu reke Orhon, ratovima i načinu života. Ovi natpisi nalaze se na Orhonskim spomenicima. Zbog specifičnosti samih spomenika koji podsećaju na nadgrobne spomenike od kamena, predstavljaju retku vrstu pisanih izvora. Naročito su značajni za istoriju turskog naroda jer se na njima prvi put pojavljuje naziv Turk (Türk). Njihova sadržina otkriva mnoge podatke o životu Turaka toga vremena i kaganima koji su bili zaslužni za okupljanje turskih naroda, kao i za osnivanje kaganata. Po trojici najuspešnijih i najznačajnijih kagana nazvana su tri spomenika. Pismo ovih natpisa podseća na germanske rune, pa se pored šire poznatog naziva goktursko ili koktursko pismo (nazvano po Gokturcima, odnosno Kokturcima), neretko naziva i turskim runama.

Ključne reči: Orhonski spomenici, Orhonski natpisi, Gokturci, Kokturci, Turci, turski jezik

\section{Uvod}

Turci su kroz svoju bogatu istoriju u trajanju od četiri hiljade godina osnivali države na različitim geografskim prostorima. Njihovo prvobitno stanište, gde su i osnovali svoju prvu državu sa nazivom „Türk” 552. godine i koja je trajala do 10. veka, bilo je područje Altaja u Centralnoj Aziji. Bežeći ka zapadu pred Mongolima, jedan ogranak turskih oguskih plemena osnovao je 1040. godine seldžučku državu u Horasanu (pokrajina u današnjem Iranu). Posle bitke kod Mancikerta 1071. godine kada su Vizantinci pretrpeli veliki poraz, Turci su nastavili da osnivaju maloazijske begluke na prostoru današnje Anadolije. Plemenski emir i seldžučki vladar Osman proglasio se nezavisnim 1299. godine, a njegovi potomci su osnovali Osmanlijsko carstvo.

aleksandra.vulovic87@gmail.com 
Delovanje na različitim kontinentima dovodilo je Turke u kontakt sa drugim kulturama. Prva kultura sa kojom su se susreli bila je kineska. Nakon kineske, dolazili su u dodir sa indijskom, vizantijskom, arapskom i na kraju sa kulturom zapadnih zemalja. Značajna odlika Turaka je činjenica da su pored stalne interferencije sa drugim civilizacijama, kulturom i načinom života, uspeli da očuvaju svoj identitet. Međutim, za prve istorijske podatke Turaka zaslužni su Kinezi, dok za prva arheološka istraživanja njihovih pisanih izvora zasluga pripada Rusima. Iako su Rusi prvi predstavili to otkriće, obaveštavanje o pronalsku prvih turskih pisanih izvora među širim naučnim krugovima sprovelo je finsko arheološko društvo (Halaçoğlu, 2014: 55). Raspadom Sovjetskog Saveza i nastankom nezavisnih turskih država Turci su počeli mnogo više da istražuju svoju istoriju, uključujući i Orhonske natpise, najstarije pisane izvore Turaka. Orhonski natpisi (Orhon Yazıtlart) pronađeni su u Mongoliji, u slivu reke Orhon 1889. godine, po kojoj su i dobili ime. Pošto su ispisani na kamenu, nazivaju se još i Orhonskim spomenicima (Orhon Abideleri). Turski lingvista Muharem Ergin (Muharrem Ergin) ističe da su ,prvi turski tekstovi u kojima se spominje ime Turčin (Türk) i turski narod, prva istorija Turaka, istorija ispisana na kamenu” (2004: 14). Prema Mariji Đukanović „To je u početku možda bio naziv samo za jedno pleme, ali kasnije postaje etnički termin, kojim su Arapi i Grci, došavši u dodir sa starom nomadskom državom, nazivali sve narode koji su govorili ovim jezikom" (1982: 186).

Orhonski natpisi potiču iz 7. i 8. veka. Njihov pronalazak koji je privukao pažnju mnogih naučnika, a posebno turkologa, predstavlja značajan momenat za razvoj turske istoriografije. Orhonski natpisi svedoče o periodu Gokturaka (Göktürk ili Köktürk). Gokturci su narod koji je potekao od Huna. U periodu od 6. do 8. veka vladali su velikim turskim kaganatom u Aziji. Ozbiljna pretnja njihovom kaganatu bila je Kina koja je 630. godine preuzela vlast nad istočnim delom kaganata. Vremenom je dominacija Kineza počela da se širi i na zapadni deo kaganata sve do 680. godine kada je tome došao kraj. Naime, istaknuti vladar Iltiriš kagan (İlitiş Kağan) je u periodu od 680. do 682. godine uspeo da povrati nekadašnji kaganat. Nakon smrti Iltiriš Kagana, kaganat su vodili njegovi sinovi Bilge kagan (Bilge Kăgan) i Kul Tigin (Kül Tigin). Bilge kagan je uz pomoć tasta Tonjukuka (Tonyukuk) još više ojačao kaganat. Nažalost, ubrzo nakon smrti braće Bilge kagana (734. godine) i Kul Tigina (731. godine), tačnije, deset godina od njihove smrti, kaganat Gokturaka prelazi u ruke Ujgura. 
Gokturci su od davnina do danas u istoj meri značajni za Turke i sve turske narode. Turci ovom drevnom narodu duguju veliku zahvalnost za širenje njihovog nacionalnog imena, kulture i istorije za koju se smatra da počinje pojavom Gokturaka. Njihov značaj upotpunićemo mišljenjem Ahmeta Tašagila (Ahmet Taşağll) koji ističe da su se turski nacionalni identitet i kultura širili posredstvom Gokturaka koji su dali pravac turskoj istoriji (Taşağıl, 2014:15).

U slivu reke Orhon pronađeno je više Orhonskih spomenika. Najpoznatiji među njima su pisani spomenici nastali za vreme vladavine Bilge kagana i Kul Tigina. Bilge kagan je nakon smrti brata Kul Tigina podigao spomenik u njegovu čast, dok je spomenik Bilge kaganu podigao njegov sin. Pored ova dva, još jedan se svrstava u najznačajnije i najviše istraživane spomenike. To je spomenik posvećen Tonjukuku, glavnom pomoćniku Iltiriš kagana i velikom državniku, koji je on za života podigao samome sebi. Iako je u slivu reke Orhon pronađeno više pisanih spomenika, naučnici pominju šest koji imaju svoje nazive. Naučnik Javuz Tanjeri (Yavuz Tanyeri) u svom priručniku za učenje kokturskog pisma posebno naglašava da su spomenici Kul Tigina, Bilge kagana i Tonjukuka spomenici na koje prvo pomislimo kada se govori o Orhonskim natpisima. Ovu pojavu objašnjava činjenicom da su pomenuti natpisi najznačajniji zbog podataka koji se u njima nalaze (Tanyeri, 2009: 3). Ne treba zanemariti i ostale manje poznate natpise. Shodno tome, navodimo svih šest poznatih Orhonskih natpisa. To su: Kul Tigin (Kül Tigin, KT 732), Bilge kagan (Bilge Kağan, BK 735), Tonjukuk (Tonyukuk, T 720 - 725, ili nakon 732. godine), Čojren (Çoyren Yazıtı, Ç 688 - 692), Kuli Čor (Küli Çor, KÇ 719 - 723), Ongin (Ongin, O 732 - 735), (Ata, 2011: 59). ${ }^{1}$

Muharem Ergin koji je među prvima preveo na savremeni turski jezik delove iz Orhonskih natpisa sa spomenika Bilge kagana, Kul Tigina i Tonjukuka, smatra da je pronalazak Orhonskih natpisa jedno od najvećih ljudskih otkrića (2004: 20). Mirjana Teodosijević takođe smatra da je otkrivanje Orhonskih natpisa od velikog značaja, posebno za razvoj naučne turkologije (2015: 363). Od 1990. godine u Turskoj počinju da se vrlo detaljno proučavaju Orhonski natpisi što je rezultiralo velikim brojem naučnih radova na tu temu. Projekat „Turci” (Türkler) ${ }^{2}$ predstavlja najobimnije istorijsko istraživanje na svetu o istoriji, kulturi i civilizacijama turske na-

$1 \quad$ U zagradi su date skraćenice ovih natpisa kao i godine kada su nastali.

2 Enciklopedija Turaka (Türkler Ansikolpedisi). 
cije koje je objavljeno na turskom i engleskom jeziku pod rukovodstvom Hasana Dželala Guzela (Hasan Celâl Güzel), bivšeg ministra za nacionalno obrazovanje, omladinu i sport Republike Turske. Ovo delo nam daje dragocene podatke o poreklu Turaka od najstarijih vremena do danas i njihovom uticaju na uobličavanje svetske istorije (Celâl Güzel, 2014). ${ }^{3}$

Značajna uloga u istoriji turskog naroda pripada kineskim izvorima. Još pre pronalaženja Orhonskih natpisa Turci se pominju u nekima od njih. „Kineski izvori daju bliže podatke o pojedinim turskim plemenima još u drugom veku pre naše ere" (Đukanović, 1982: 186). Jedan podatak koji je od posebnog značaja za tursku istoriju poznat nam je upravo iz tih kineskih izvora, a odnosi se na poreklo imena Türk. „Ime Türk znači snaga, snažan. Javlja se u kineskim hronikama iz 552. godine kao T'u - küe ( $\mathrm{Ti}-\mathrm{k}-\mathrm{ue}$ )" (Teodosijević, 2015: 366).

Muharem Ergin iznosi podatak da je još u 12. veku istoričar Džuvejni (Alaüdin Ata Melik Cüveyni) u svom delu Tarih-i Cihanküşa govorio o Orhonskim natpisima. Ovaj istoričar je tvrdio da postoje natpisi na stenama i da ih je on video (Ata, 2011: 60). Postoje i natpisi koji su pronađeni pre Orhonskih natpisa koji nisu istraženi u dovoljnoj meri zbog nemogućnosti dešifrovanja. Ovi pisani spomenici nisu odoleli vremenu kao Orhonski, dosta su oštećeni što je naučnicima dodatno otežavalo njihovo dešifrovanje. Poznati su kao Jenisejski natpisi (Yenisey Yazıtları) po reci Jenisej u čijem su slivu i pronađeni. ,Jenisejski natpisi su natpisi za koje se smatra da su podignuti od strane Kirgiza i danas njihov ukupan broj iznosi 250" (Aydın, 2012: 161). Prve podatke o postojanju ovih natpisa daje nam izaslanik ruskog cara N. Milesko (N. Milesco). On pominje natpise za koje se ne zna šta predstavljaju i ko ih je napisao (Ata, 2011: 61). Jenisejske natpise pronašli su krajem 1721. godine naučnici Štralenberg (Strahlenberg) i Meseršmit (Messerschmidt). Godine 1730. Štralenberg objavljuje knjigu u kojoj govori o natpisima pronađenim u slivu reke Jenisej i objavljuje čak i neke natpise. Objava ovih natpisa pokrenula je lavinu interesovanja naučnika koji će pokušavati da ih dešifruju. Međutim, ti natpisi će biti samo uvertira za Orhonske natpise koji će svojom kompleksnošću nadmašiti prvopronađene, odnosno Jenisejske. Kada su Jenisejski natpisi pronađeni o njima se ništa nije znalo ni kome pripadaju, ni kada su nastali, a njihovo pismo nikome nije bilo poznato. Nakon što ih je danski naučnik Vilhelm Tomsen (Wilhelm Thomsen) dešifrovao, došlo je do napretka u njihovom 
čitanju. Ni na jednom od ovih spomenika ne postoje nikakve vremenske oznake. Iako se smatra da u to vreme nije postojao kalendarski sistem, neki naučnici tvrde da su nastali pre Orhonskih natpisa. Međutim, preovladava mišljenje da ovi natpisi nisu stariji od Orhonskih, već da potiču iz perioda između 9. i 10. veka. Karakteristika Jenisejskih natpisa je ta što ne govore o konkretnim istorijskim događajima. Natpisi se odnose na pojedine junake i govore o tome šta su oni radili, kako su umrli, o njihovim porodicama. Na pojedinim spomenicima su zapisane impresije o suncu i mesecu junaka kome je posvećen natpis. Budući da ovi natpisi nemaju neku posebnu istorijsku važnost, nisu bili predmet interesovanja turskih naučnika. Pronalaskom Jenisejskih natpisa počele su da se organizuju razne ekspedicije kako bi se došlo do novih saznanja. Istraživanja ove ekspedicije rezultirala su otkrićem Orhonskih natpisa.

\section{Pronalazak Orhonskih natpisa}

Orhonski natpisi su pronađeni 1889. godine u vreme dok je finski istraživački komitet istraživao Jenisejske natpise (Tekin, 1968: 13). Istraživanja prve ekspedicije poslate iz Finske u Sibir rezultirala su objavljivanjem kopija Jenisejskih natpisa 1889. godine. Iste godine ruski arheolog N. M. Jadrincev (N. M. Yadrintsev) pronašao je na obali reke Orhon dva spomenika sa istim pismom, ali daleko veća od Jenisejskih. Iz Enciklopedije Turaka saznajemo tačan datum pronalaska Orhonskih natpisa, „Orhonski natpisi, pronađeni su 18. jula 1889. godine od strane ruske delegacije koju je predvodio N. M. Jadrincev" (Halaçoğlu, 2014: 55). N. M. Jadrincev je 1890. godine objavio delo pod nazivom Orhonski natpisi. U ovom delu pisao je o dva velika natpisa koja je pronašao. Nakon ovog novog otkrića u Mongoliji, Finci opet organizuju ekspedicije. Kao rezultat svojih naučnih istraživanja 1892. godine objavljuju odlične kopije Orhonskih natpisa (Tekin, 2014:1). Pošto su ove kopije objavljene i u Rusiji, ruski naučnici krenuli su u naučnu misiju. Sa jedne strane finska, sa druge ruska ekspedicija pod vođstvom ruskog orijentaliste nemačkog porekla V. Radlova imale su ogroman naučni doprinos. I jedna i druga ekspedicija sa dragocenim podacima i fotografijama uspele su da privuku pažnju mnogim drugim naučnicima. Fotografije Orhonskih spomenika objavljene su u tzv. velikom Atlasu (Ergin, 2014: 22), gde je na jednom od spomenika primećen deo napisan na kineskom jeziku. Ono što se tada otkrilo iz natpisa na kineskom jeziku, jeste da je jedan od spomenika podignut 732. godine 
$\mathrm{u}$ čast jednog preminulog turskog princa. Na osnovu tog prvog otkrivenog podatka postalo je izvesno kome ovi natpisi pripadaju i na kom su jeziku napisani. „Ova dva natpisa su ostatak turskih praotaca; Jezik koji je korišćen ne može biti ništa drugo osim jedan od starih turskih dijalekata" (Tekin, 2014: 1). Objavljivanjem ovog atlasa ubrzao se rad na dešifrovanju natpisa. Vilhelm Tomsen je 1893. godine uspeo da dešifruje orhonsko pismo. On je 15. decembra 1893. godine u Akademiji nauka Kopenhagena, na jednom skupu izjavio da je dešifrovao rune na Orhonskim i Jenisejskim natpisima. Nazvao ih je runama jer su neverovatno podsećale na germanske rune. Ovo je bio ključni momenat za Turke i njihovu istoriju. Dešifrovanje pisma olakšalo je rešavanje natpisa i njihovog dragocenog sadržaja.

Mnogim naučnicima, posebno turkolozima, otkriće i dešifrovanje pisma Orhonskih natpisa bilo je od velikog značaja za dalji naučni rad. Većina je pokušavala da dešifruje natpise, a najuspešniji među njima bili su V. Tomsen i V. Radlov. Za njih je karakteristično da su počeli u to vreme da se takmiče ko će prvi da objavi prevode određenih delova natpisa. V. Radlov je 1894. godine objavio delo o Orhonskim i Jenisejskim natpisima, ali pošto ga je pripremao u žurbi takmičeći se sa V. Tomsenom, obilovalo je greškama. Suprotno od V. Radlova, V. Tomsen je, ne žureći, objavio 1896. godine delo koje se sastojalo iz dva dela. Prvi deo bio je posvećen turskim runama, načinu njihovog pisanja i primerima. U drugom delu pisao je o turskoj istoriji i dao je prevode dva natpisa na turski i francuski jezik. U njegovom delu se nalazi i deo natpisa na spomeniku Kul Tigina koji je preveden na kineski jezik. Takođe je dat i prevod na engleski jezik natpisa na kineskom. Ovo Tomsenovo delo je bilo vrlo zapaženo. „Naučnici koji su kasnije radili na Orhonskim natpisima u okviru svojih istraživanja uzimali su ovo delo za primer" (Tekin, 2014: 2). Pošto je u svom prvom delu o Orhonskim i Jenisejskim natpisima napravio dosta grešaka, V. Radlov je u svojim potonjim radovima s mnogo više pažnje pristupao ovoj temi. Značajno je da napomenemo da je u Turskoj prvo delo o Orhonskim natpisima objavio Nedžib Asim (Necib Asım) 1924. godine pod naslovom Orhonski spomenici (Orhon Abideleri). On je delo pripremio koristeći dela V. Tomsena i V. Radlova. Budući da je napisano arapskim pismom danas ima istorijsku vrednost. Drugo po redu delo objavljeno u Turskoj o Orhonskim natpisima je Stari turski natpisi (Eski Türk Yazttlart) koje je napisao H. N. Orkun (H. N. Orkun). Delo je izlazilo u periodu od 1936. do 1941. godine u četiri toma. 
Mnogi naučnici širom sveta su objavljivali radove na temu Orhonskih i Jenisejskih natpisa. Među najuspešnijim su bili ruski naučnici, a zatim mađarski i nemački turkolozi koji su takođe bili uspešni u izučavanju pomenutih natpisa. Za turkologe je značajno delo Orhonski spomenici poznatog turskog lingviste Muharema Ergina, objavljeno 1970. godine. U njemu su dati delovi natpisa Kul Tigina, Bilge kagana i Tonjukuka sa prevodom na turski i rečnikom. U svojoj knjizi pominje i naučnika Talata Tekina (Talat Tekin) koji je u Americi objavio gramatiku Orhonskih natpisa, kao i same natpise. Ova dva dela predstavljaju osnovno štivo za izučavanje Orhonskih natpisa.

\section{Alfabet}

Postoje razne teorije o poreklu alfabeta Orhonskih natpisa. Jedna od usvojenih je teorija V. Tomsena. On je tvrdio da je stari turski alfabet izveden od aramejskog alfabeta sa mogućim primesama iranskog jezika (Tekin, 1968: 26). Marija Đukanović smatra da je „ovo pismo nastalo po ugledu na neko prednjeazijsko pismo, mada je sada teško pouzdano utvrditi koje" (1982: 187). Značajna karakteristika ovog pisma jeste i činjenica da je bilo ,sasvim podesno i prilagođeno fonetskoj strukturi turskog jezika", ističe Marija Đukanović (1982: 187). Orijentalista Žerard Klauson (Sir Gerard Clauson) koji je istraživao poreklo starog turskog alfabeta, došao je do zaključka da se od ukupno dvadeset dva slova aramejskog / iranskog alfabeta petnaest koristilo kao model za stvaranje turskog alfabeta (Tekin, 1968: 27). „Nije važno kako je osmišljeno ili nastalo, već je važno to da je pismo turskih runa, nesumnjivo, jedno od najgenijalnije smišljenih alfabeta prvog milenijuma" (1968: 27). Ne zna se kada je tačno nastalo i kada je počelo da se koristi, ali se smatra da je svakako starije od Orhonskih natpisa koji datiraju iz prve polovine osmog veka. Alfabet ovih natpisa poznat je kao orhonsko ili goktursko pismo (Orhon veya Göktürk Yazısı), kao i tursko runsko pismo (Türk runik yazısı). Termin orhonski turski predstavlja jezik korišćen u Orhonskim natpisima, ali i do ovog naziva se postepeno došlo, jer su naučnici davali različite nazive dok se nisu usaglasili da je ovaj najadekvatniji. V. Radlof je na samom početku dao naziv „stari turski”, V. Bang ga je nazvao „kokturskim”, a V. Tomsen je predložio nazive „stari turski”, „turske rune”, „stari orhonski turski”, ili najjednostavnije „orhonski turski” (Tekin, 1968: 8). U jednom periodu je često korišćen termin „stari turski”, pa je ruski naučnik dao naziv „drevni 
oguzski" koji je bio apsolutno neodgovarajući, tako da je vremenom prihvaćen naziv „orhonski turski” koji se i danas koristi.

Orhonsko pismo sadrži trideset osam slova ili znakova, kako se još nazivaju zbog svojih karakterističnih oblika koji podsećaju na germanske rune. Od trideset osam slova, samo četiri predstavljaju vokale (Tekin, 2014: 9). Poznato je da je turski jezik bogat vokalima i da ih ima čak osam, ali u orhonskom pismu je specifično upravo to što su samo četiri znaka bila za obeležavanje vokala. Međutim, svaki znak je imao dvojnu vrednost, drugim rečima, u orhonskom pismu za vokale A / E, za I / İ, O / U i Ö / Ü koristilo se po jedno slovo (znak). Zanimljivo je da deset konsonanata B, D, G, K, L, N, R, S, T, i Y predstavlja dvadeset, jer svaki od njih ima svoj parnjak, odnosno svaki ima po dva slova za obeležavanje bezvučnih i zvučnih konsonanata. Postoje i dva konsonanta koji označavaju slogove sa vokalima. U zavisnosti od vrste vokala postoje različiti slogovi (ok / ko, ök / kö, ik / ki, iç / çi; mogu označavati i uk / ku, kao i ük / kü). Karakteristična je i pojava dvojnih konsonanata kao što su: LT, NÇ i NT. U Orhonskim natpisima česta je pojava nebeleženja vokala i to po pravilu na početku ili u sredini reči. Izuzetak je dugo A koje se uglavnom pisalo. Jedna od najvažnijih karakteristika Orhonskih spomenika jeste način na koji su pisani natpisi. Pisani su sa desna na levo, a dve tačke imale su ulogu u odvajanju reči. Ostali znakovi interpunkcije nisu postojali, osim pomenute dve tačke koje su imale separativni karakter. Ono što ovo pismo čini još zanimljivijim, ali i težim, jeste to što su između spomenika postojale razlike u pisanju nekih slova. Prema Muharemu Erginu čak je deo slova orhonskog alfabeta imao više načina za pisanje. On je ovu tvrdnju potkrepio činjenicom da između tri najpoznatija spomenika Kul Tigina, Bilge kagana i Tonjukuka ima mnogo razlika u pisanju (Ergin, 2004: 30).

\section{Orhonski spomenici}

U sadašnjoj Mongoliji, u blizini starog korita reke Orhon, u okolini jezera Kočo Čajdam (Koço Çaydam) nalaze se Orhonski spomenici. Najčuveniji i najproučeniji sapomenici od poznatih šest, su tri iz kojih se saznaju podaci o vremenu njihovog nastanka. Podignuti su u prvoj polovini 8. veka. Kao najraniji turski pisani izvori imaju nemerljiv kulturni i istorijski značaj. Marija Đukanović Orhonske spomenike smatra prvim književnim spomenicima jer su: ,,pisani sažetim jezikom, mada im je stil živ i nije sveden na iznošenje golih činjenica, kao što je čest slučaj u epigrafskim 
dokumentima" (1982: 187). Kako bi sačuvala i zaštitila Orhonske spomenike, Republika Turska je 1995. godine započela jedan značajan projekat. Turska agencija za saradnju i razvoj, poznatija kao TIKA (Türk Iş̧birliği ve Kalkınma Ajansi) sa Ministarstvom za obrazovanje, kulturu i nauku Mongolije pokrenula je projekat pod nazivom „Projekat turskih spomenika koji se nalaze u Mongoliji” (MOTAP). Metin Orbaj (Metin Orbay) u jednom svom radu piše o prvom obilasku Orhonskih natpisa i opisuje put do samih spomenika. Po njegovim rečima, put je bio iscrpljujući sve dok nisu videli tursku zastavu i natpis „,autoput Bilge kagana”, čija je izgradnja predstavljala deo projekta. Put je vodio do muzeja gde su se nalazili spomenici Bilge kagana i Kul Tigina (Orbay, 2013: 338).

\subsection{Spomenik Kul Tigina}

Nakon smrti Kul Tigina, njegov brat Bilge kagan je želeo da na nesvakidašnji i trajan način iskaže zahvalnost koju je osećao prema svom bratu čiji su junaštvo, hrabrost, zalaganje bili od presudnog značaja za jačanje i stabilizovanje tadašnjeg turskog kaganata. On je lično osmislio ovaj spomenik kao trajno svedočanstvo jedne epohe turske države. U periodu podizanja spomenika, Bilge kagan je sedeo ispred njega i nadgledao nastajanje dela (Ergin, 2004: 17). On je takođe bio i narator natpisa. Spomenik Kul Tigina je postavljen na bazni kamen u obliku kornjače pored koga je pronađen prevrnut. U tom stanju je bilo neizbežno da spomenik bude oštećen. Neki delovi na njemu su bili izbrisani. Kasnije je uspravljen i njegova visina iznosi $3,75 \mathrm{~m}$. Nije tačno utvrđeno poreklo kamena, ali se smatra da je od krečnjaka ili mermera. Širi se od donjeg dela ka gornjem. Ima četiri strane. Širina istočne i zapadne strane u donjem delu je $132 \mathrm{~cm}$, a u gornjem $122 \mathrm{~cm}$, dok je kod severne i južne u donjem delu $46 \mathrm{~cm}$, u gornjem $44 \mathrm{~cm}$. Spomenik je do visine od $2.75 \mathrm{~m}$ sa svih strana prekriven natpisima. Za ovaj spomenik je karakteristično postojanje natpisa na kineskom jeziku koji se nalaze na zapadnoj strani. Preostale tri strane su od početka do kraja ispisane natpisima na turskom jeziku. „Jezik Orhonskih natpisa nije neki apstraktni praturski, već jedan stari dijalekt" (Đukanović, 1982: 187). Istočna strana spomenika sadrži četrdeset redova, dok na severnoj i južnoj strani ima po trinaest redova. Na baznom kamenu nalazi se osam redova, ali samo se sedam do osam reči može pročitati. Redovi su ispisani odozgo na dole i sa desna na levo. Njihova dužina iznosi približno $235 \mathrm{~cm}$. Prilikom opisivanja izgleda natpisa Muharem Ergin navodi „da 
su pisani tako pravilno i uredno lepim slovima kao da je korišćen lenjir" (2004: 18). Ovaj spomenik ima ispisan datum nastanka tako da je utvrđeno da je podignut 21. avgusta 732. godine (Tekin, 2014: 7).

Bilge kagan u ovim natpisima govori o događajima koji pripadaju istoriji Gokturaka. Iskreno i kritički daje savete kako bi Turci živeli ujedinjeno i složno. U jednom od natpisa on kaže: „Turska gospodo i narode čujte ovo: Ovde sam napisao da kada se turski narod skupi biće države, a napisao sam i da će umreti kada pogreše (ako se ne skupe)" (Alyılmaz, 2004: 182). Njegovi natpisi govore i o mestu gde su podignuti ovi spomenici. Bilge kagan objašnjava zašto je baš Otuken (Ötüken $)^{4}$ današnja Orhonska oblast (Orhun Bölgesi) izabrana za mesto nastajanja turske države. Ova oblast zbog svog dobrog geografskog i strateškog položaja oduvek se smatrala centrom turskog kaganata i imperije. Bilge kagan svom narodu i budućim naraštajima putem ovih natpisa prenosi poruku da je Orhonska oblast lepa, koliko je značajna za život Turaka, da se ne može naći bolje mesto gde bi se vojska uputila, u slučaju da je napuste, neće imati budućnost, a ako ostanu i bave se trgovinom biće beskrajno srećni i mirni (Alyılmaz, 2004: 183). Na južnoj strani spomenika nalazi se natpis koji glasi: „Nikada nije postojalo lepše mesto od orhonske šume. Mesto gde će nastati turska domovina i mesto kuda će se kretati je orhonska šuma. Nastanivši se na ovom mestu popravio sam odnose sa kineskim narodom" - KT G 3-55 (Alyılmaz, 2004: 183). Nije slučajnost što je Bilge kagan savetovao da se turska država osnuje baš u toj oblasti. Znao je iz iskustva prethodnih turskih kagana da ta oblast predstavlja deo „Puta svile” (Ípek yolu) ${ }^{6}$ koji će im omogućiti trgovinu sa ostalim zemljama. „Prvo su Huni zatim i Gokturci vodili ratove i borbe da bi uspeli da prodaju i dopreme Vizantiji svilu koju su uzimali na ime poreza od Kine i gvožđe koje su sami proizvodili, kao i proizvode od gvožđa" (Alyılmaz, 2004: 184). Potražnja za svilom i gvožđem kao i raznim njihovim proizvodima bila je velika što je Turcima zahvaljući Putu svile bilo od velikog značaja za razvoj trgovine i trgovinskih odnosa sa drugim zemljama. Bilge kagan je iz navedenih razloga želeo da se Turci nastane u

4 U natpisima se ova oblast pojavljuje pod nazivom Otuken (Ötüken).

$5 \quad$ KT je oznaka za natpise na spomeniku Kul Tigina. Sledeća oznaka je slovo koje označava stranu natpisa, dok brojevi predstavljaju redove natpisa. Stoga, skraćenica od Kul Tigin je KT, G predstavlja južni deo, a brojevi 3-5 označavaju redove natpisa.

6 Jedan od najstarijih i najprometnijih puteva za razmenu dobara koji se pružao od Azije do Evrope i od Evrope do Afrike. 
Orhonskoj oblasti. U jednom od natpisa kaže: „Turski narode, ako se nastanite na Orhonskoj zemlji, i ako budete slali karavane nikakve muke imati nećete. Ako budete živeli u Orhonskoj šumi do kraja ćete vladati državom" (KT G 8), (Aly1lmaz, 2004: 183). On je i mesto gde će se podići spomenik pažljivo odabrao, jer i u jednom delu natpisa govori da je spomenik podigao na mestu do kojeg je lako doći. Spomenik je u natpisima nazvao „večnim kamenom” (ebedi taş). „Dao sam da se iskleše i ispiše večni kamen na jednom takvom mestu do kojeg se lako dolazi. Kada ga budete videli, tako ćete znati i naučiti” (KT G 12-13), (Aly1lmaz, 2004: 185).

Jedan od najpoznatijih natpisa na spomeniku Kul Tigina odnosi se na osnivanje turskog kaganata i najistaknutije kagane tog doba. Ovaj natpis glasi: „Kada je sa gornje strane stvoreno plavo nebo, a s donje crna zemlja, između njih stvoreni su ljudi. Nad ljudima su se uzvisili moji preci Bumin kagan i Istemi kagan. Pošto su postali majstori (svoga posla), upravljali su imperijom turskoga naroda i njenim ustanovama. Na sve četiri strane sveta imali su mnogo neprijatelja, ali kada su krenuli sa vojskom u pohode, porobili su mnoge narode na sve četiri strane sveta, prevaspitali ih, potčinili i pokorili.; naselili su napred (to je prema istoku) šumu Kadirkan, a od pozadi (to jest na zapadu) Demir kapiju" 7 (KT D 1-2), (Ergin, 2004: 40).

Kroz ove natpise dolazimo i do saznanja o odnosima Kineza prema drugim narodima u to vreme. Sledeći natpis nam daje interesantne podatke: „Zlato, srebro, svilu i materijale od svile davali su bez ikakvih problema. Kineska reč je slatka, nežna poput svile. Zavaravajući slatkim rečima, nežnim materijalom od svile približavali su daleke narode. Približivši ih, nakon njihovog preseljenja, razmišljali su o lošim stvarima" (KT G5), (Ergin, 2004: 37). Bilge kagan je u ovim natpisima govorio o odnosu sa Kinezima za koje je smatrao da ih je on poboljšao, ali njegovo mišljenje o njima nije bilo pozitivno, što možemo zaključiti iz prethodno navedenog natpisa. Međutim, iz interesnih razloga težio je ka izgradnji dobrih odnosa sa Kinom. Dobar odnos između tadašnjih zemalja opisan je i u sledećem natpisu: „Doveo sam slikara od kineskog kagana da slika. Moju reč nije pogazio" (Ergin, 2004: 39). Ovde Bilge kagan želi da istakne poštovanje koje je uživao kod kineskog kagana.

Kao što je poznato, na zapadnoj strani spomenika Kul Tigina nalaze se natpisi na kineskom jeziku. Smatramo da je i ovaj čin samo odraz dobro

$7 \quad$ Prevod ovog natpisa je dala prof. dr Mirjana Teodosijević na predavanju iz predmeta Uvod u turkologiju. 
uspostavljenih odnosa sa Kinom za vreme stolovanja Kul Tigina i Bilge kagana. Bilge kagan je u natpisima na spomeniku Kul Tigina govorio o pomoći kineskih umetnika pri podizanju samog spomenika. Da bi izrazili svoju zahvalnost prema učtivim Kinezima, jedan od natpisa je na kineskom jeziku. Iako je Bilge kagan imao svoje mišljenje o Kinezima za koje je smatrao da se bave intrigama, zaverama kako bi privukli druge narode, a zatim ih pokorili i pripojili sebi, ponosno je govorio o korektnim odnosima tadašnjih zemalja. Jedan od njih glasi: „Iz tog razloga smo naročito podigli ovaj veličanstveni spomenik sa natpisima da bi u svesti bezbrojnih budućih generacija svakog dana iznova oživljavala slava njihovog zajedničkog trijumfa kako bi svi narodi i oni daleki (stranci) i oni koji su blizu (Turci) mogli da saznaju za to" (Aly1lmaz, 2004: 186). Pored ovih natpisa koji opisuju odnose sa Kinom, postoje i oni gde se naglašava kako je Bilge kagan okupio turski narod i siromašne obukao i nahranio. Navodimo natpis koji o tome svedoči: „Gladan, siromašan narod, sve sam ih okupio. Siromašne sam učinio bogatim. Od malog naroda napravio sam veliki. Ili u mojim rečima ima laži?" (KT G10), (Alyılmaz, 2004: 39).

\subsection{Spomenik Bilge kagana}

Spomenik Bilge kagana udaljen je jedan kilometar od spomenika Kul Tigina. Po svom obliku i stilu podseća na prvi, odnosno na spomenik Kul Tigina. Jedina razlika je u tome što je nekoliko centimetara viši. On je u poređenju sa spomenikom Kul Tigina u mnogo lošijem stanju, dosta je oštećen, a neki natpisi su potpuno izbrisani. I na ovom spomeniku postojao je natpis na kineskom jeziku koji je vremenom usled raznih oštećenja u potpunosti izbrisan. U poređenju sa spomenikom Kul Tigina, ovaj spomenik je viši i zbog toga ima i više redova. Na istočnoj strani četrdeset i jedan red, a na užim severnim i južnim stranama po petnaest redova (Ergin, 2004: 17). Karakteristično za ova dva spomenika je postojanje identičnih natpisa, ili sa manjim razlikama. Prema natpisima ovaj spomenik podignut je 735. godine. Podigao ga je sin Bilge kagana, Tenri Kagan godinu dana nakon smrti svoga oca. Sadržaj natpisa ovog spomenika je veoma sličan spomeniku Kul Tigina. Uzimajući u obzir da su oba spomenika podignuta u razmaku od tri godine, pojava da su neki natpisi identični i nije za čuđenje. Budući da su nastali u istom periodu, za vreme iste vladavine, opisuju iste događaje, s tim što je spomenik Bilge kagana bogatiji za neke događaje do kojih je došlo nakon smrti Kul Tigina. Natpisi na temu naseljavanja 
Orhonske oblasti, odnosi sa Kinezima, ratovi, borbe vođene za Put svile, doprinos Bilge kagana okupljanju turskog naroda i nastanak turskog kaganata, zastupljeni na spomeniku Kul Tigina, nalaze se i na spomeniku Bilge kagana. Navodimo prevode delova natpisa sa ovog spomenika:

„Nisam stolovao nad bogatim, imućnim narodom. Stolovao sam gladnim, neodevenim, bednim, očajnim narodom. Pričao sam sa mojim mlađim bratom Kul Tiginom. Da se ne bi izgubila čast i ime naroda koje su stvorili moj otac i stric, zarad turskog naroda noću nisam mogao da spavam, a danju sedeo nisam" (BK D 21-22), (Ergin, 2004: 43).

„Bilo nas je malo (vojska), bili smo u lošem stanju. Oguz (Oğuz)... neprijatelj... Pošto je Gospod dao snage, tamo sam se naoružao i raspodelio (vojsku). Turski narod je pobedio zato što je Gospod pomogao i zato što sam ja pobedio. Da ja nisam bio na čelu sa mojim mlađim bratom i da nisam pobedio Turski narod bi umro, iščezao bi...." (BK D 32 - 33), (Ergin, 2004: 47, 49).

„Turski narode, ne znaš vrednost sitosti. Ako ogladniš ne razmišljaš o sitosti. Ako se jednom najedeš ne razmišljaš o gladi. Zato što si takav, ne dobivši saglasnost kagana koji te je nahranio, svuda si išao. Tamo si uvek bivao uništen i poražen. Tamo si sa onima koji su ostali slabeći i umirući hodao. Ja sam vladao zato što je Gospod naredio, zato što sam ja državnik. Vladajući nad gladnima i siromašnima, sve sam ih okupio. Siromašan narod načinio sam bogatim...." (BK K 6 - 7), (Ergin, 2004: 59).

Osnivač Republike Turske Mustafa Kemal Ataturk (Mustafa Kemal Atatürk) dok je čitao jednu knjigu o Orhonskim natpisima pored natpisa: „Sve dok se sa gornje strane nebo ne spusti, a sa donje strane zemlja ne otvori, turski narode ko će moći tvoju državu, tvoje zakone da uništi i pokvari?” (BK D 18 - 19), (Tekin, 2014: 57), svojeručno je zabeležio „Veliki govor ${ }^{8}$, eto, ovu rečenicu objašnjava.",

\subsection{Spomenik Tonjukuk}

Bilge Tonjukuk je od vremena Iltiriš kagana, pa do Bilge kagana bio glavni pomoćnik u državnoj upravi i glavni komandant vojske. Bio je jako poštovan od strane Iltiriš kagana, kasnije i Kul Tigina i Bilge kagana

8 Govor (Nutuk) koji je održao Mustafa Kemal Ataturk od 15. do 20. oktobra 1927. godine.

9 Preuzeto sa sajta: http://www.orhunyazitlari.com/kisa-bilgi.html 
zbog svoje sposobnosti i umeća da rukovodi državom. Ostao je poznat kao veliki turski državnik. Poznato je da je kada se Iltiriš kagan sa sedamnaest osoba suprotstavio Kini, Bilge Tonjukuk bio jedan od tih sedamnaest. U starosti je sam podigao taj spomenik na kojem je pisao svoja sećanja. Uglavnom se ta sećanja odnose na ratove i borbe koje su vodili i u kojima je Tonjukuk učestvovao. Ako ćemo ovaj spomenik vrednovati po njegovoj sadržini, onda se može reći da je Bilge Tonjukuk prvi koji je pisao o svojim sećanjima. Za njegov spomenik je karakteristično to što se sastoji od dva kamena. Prvi je veći i ima 35 redova, dok se na drugom nalazi 27 redova. U poređenju sa spomenicima Bilge kagana i Kul Tigina ovaj spomenik nije tako čitko i uredno napisan. Nalazi se malo istočnije od spomenika Bilge kagana i Kul tigina. Kao i prethodni spomenici ima četiri strane, ali je način pisanja drugačiji. Naime, na ovom spomeniku se pisalo odozgo na dole, a ne s leva na desno kao što je slučaj sa spomenicima Bilge kagana i Kul Tigina. Iako se ne zna tačno kada je podignut smatra se da pripada vremenu vladavine Bilge kagana između 716. i 734. godine.

Jedan od poznatih natpisa sa spomenika Bilge Tonjukuk glasi: „Da Iltiriš kagan nije pobedio i da ja nisam pobedio i pokrajina i narod bi iščezli. Zato što je pobedio i zato što sam ja pobedio pokrajina je postala pokrajina, a narod je postao narod. Ja sam postao starac, ostario sam. Ako na bilo kom mestu postoji narod sa ovakvim kaganom, kakav problem bi se mogao pojaviti? Napisao sam u pokrajini turskog Bilge kagana. Ja, Bilge Tonjukuk" (BT D 4 - 6), (istočna strana spomenika), (Ergin, 2004: 81).

„Pošto je Iltiriš kagan bio inteligentan i hrabar, ratovao je protiv Kine jedanaest puta, protiv Kitaja (Kitay) sedam, protiv Oguza (Oğuzlar) pet puta. Kod njih sam opet lično ja bio izaslanik, bio sam i lično njegov (Iltiriš kaganov) komandant. Iltiriš kaganu, turskom Bogu (Bögü) kaganu i turskom Bilge kaganu" (BT G 4 - 6), (južna strana spomenika), (Ergin, 2004: 79).

\section{Zaključak}

Prapostojbina Turaka, domovina tadašnjih Gokturaka, iako je veoma udaljena od sadašnje Republike Turske sa kulturološkog i istorijskog aspekta predstavlja dragoceno blago turskog naroda. Orhonski spomenici kao najraniji pisani izvori o Turcima sa svim svojim specifičnostima i jedinstvenošću obeležili su period rane turske istorije. Njihovim pronalaskom turska istorija je upotpunjena. Pronalaženjem, kasnije i dešifrovanjem Orhonskih natpisa pokrenuta su razna naučna istraživanja kako 
bi se sadržina tih natpisa obelodanila. Natpisi na tim spomenicima nisu u potpunosti očuvani, a da bi se sačuvali od daljih oštećenja Republika Turska u saradnji sa Mongolijom izgradila je muzej u kojem se danas ovi spomenici čuvaju.

Najstariji među spomenicima je Čojren (Çoyren) za koji se smatra da je podignut u 7. veku, tačnije između 688. i 692. godine. Iako je ovaj spomenik najstariji pisani spomenik Turaka, zbog svoje oskudnosti (sadrži samo šest redova) ne ubraja se u najvrednije. Tri spomenika koja su nastala oko četrdeset godina kasnije, a to su već poznati spomenici Bilge kagana, Kul Tigina i Tonjukuka, predstavljaju najznačajnije turske pisane izvore sa istorijskog i lingvističkog gledišta. Ovi spomenici su od vremena kada su pronađeni do danas predmet brojnih istraživanja. Postoji ogromna vremenska distanca od nastanka do pronalaženja Orhonskih spomenika. Orhonski natpisi su u velikoj meri oštećeni, a pored nekih izbrisanih delova unutar natpisa, postoje $\mathrm{i}$ oni potpuno uništeni i izbrisani.

Usled takvih okolnosti natpisi ova tri spomenika nisu potpuni. Oslanjajući se na one delove koji su čitki i neoštećeni, nakon dešifrovanja Orhonskog alfabeta naučnici rade na transkripciji natpisa i njihovom približavanju savremenom turskom jeziku. Zahvaljujući njima, sada se Orhonski natpisi mogu nesmetano čitati, što dovodi do mnogih saznanja o načinu života tadašnjih Turaka, njihovim ratovima, odnosima sa drugim zemljama i ostalo.

Pored spomenika u Orhonskoj oblasti su pronađene i druge istorijske znamenitosti, poput raznih statua i skulptura kagana, ali se njima nije posvetila dovoljna pažnja, jer su u prvom planu bili Orhonski natpisi. Kako godine prolaze, Turci pridaju sve veći značaj Orhonskim natpisima. Mnogi naučnici izučavaju i pišu na temu Orhonskih natpisa. U novije vreme su počela detaljnija istraživanja Orhonske oblasti. Poznati naučnik Muharem Ergin u predgovoru svoje knjige Orhonski spomenici, Orhonske spomenike naziva ,prvom turskom istorijom i velikim dokumentom turskog poretka, turskih običaja, turske civilizacije i uzvišene turske kulture" (Ergin, 2004: 14). Ono što je veoma karakteristično i od velikog značaja ne samo za Turke već i za Kineze jesu natpisi na kineskom jeziku. Zanimljiva je činjenica da se prvi podaci o poreklu Turaka nalaze u kineskim izvorima, a na prvim pisanim turskim izvorima nalaze se i natpisi na kineskom. Dolazimo do zaključka da su se istorije Kineza i Turaka stalno preplitale, a njihovi „komšijski” odnosi trajali vekovima unazad. 


\section{LITERATURA}

Ata, A (2011). Orhun Türkçesi. Eskişehir: Anadolu Üniversitesi.

Alyılmaz, C. (2004). Ipek Yolu ve Orhun Yazıtları. Türkiyat Araştırmaları Enstitüsü Dergisi, Sayı 24, 181-192.

Aydın, E. (2012). Yenisey Yazıtları Nasıl Tarihlendirilebilir?. In S. Üst (ed), International Periodical For The Languages. Literature and History of Turkish or Turkic. (Volume 7/2, pp. 161-169). Ankara

Celal Güzel, H. (2014). Sunuş. In H. C. Güzel, K. Çiçek, S. Koca (ed), Türkler Ansiklopedisi. (Cilt I, predgovor). Ankara: Yeni Türkler Yayınları.

Đukanović, M. (1982). Turska književnost. In K. Krsnik (ed), Povijest svjetske književnosti. (pp. 186-218). Zagreb: Mladost

Ergin, M (2001). Orhun Abideleri. İstanbul: Boğaziçi Yayınları.

Halaçoğlu, Y. (2014). Türk Tarihi Üzerinde Çalışmalar. In H. C. Güzel, K. Çiçek, S. Koca (ed), Türkler Ansiklopedisi. (Cilt I, pp. 55-60). Ankara: Yeni Türkler Yayınları.

Orbay, M. (2013). Orhun Yazıtlarına dokunmak. Uluslararası Türkçe Edebiyat Kültür Eğitim Dergisi, Sayı 2/4, 335-345.

Taşağıl, A. (2014). Göktürkler, In H. C. Güzel, K. Çiçek, S. Koca (ed), Türkler Ansiklopedisi. (Cilt II, pp. 15-49). Ankara: Yeni Türkler Yayınları.

Tekin, T. (1968). A Grammar of Orkhon Turkic. Bloomington: Indiana University.

Tekin, T. (2014) Orhon Yazıtları, Ankara: TDKY

Teodosijević, M. (2015). Turski svet: Turci i turski jezici. In Lončar - Vujnović M. (ed), Susreti naroda i kultura u lingvistici, sociolingvistici, psiholingvistici. (pp. 361-369). Kosovska Mitrovica: Filozofski fakultet Univerziteta u Prištini.

Tanyeri, Y. (2009). Göktürk Yazısını Öğrenme Kılavuzu. Dostupno preko: https://www.bilgicik.com/dosya/gokturk-yazisini-ogrenme-kilavuzu.pdf [30.03.2017. ] 


\title{
Aleksandra Vulović
}

\section{THE OLDEST TURKISH WRITTEN MONUMENTS}

\begin{abstract}
Summary
The Orkhon inscriptions are the oldest written sources about the Turks, their first settlement in the Orkhon River basin, wars and way of life. These inscriptions are on the Orkhon Monuments. Due to the specificity of the monuments themselves, which resemble stone tombstones, they represent a rare type of written sources. They are particularly significant for the history of the Turkish people because it is the first time that the the name Turk (Türk) appears on a monument. Their contents reveal to us a lot of information about the life of the Turks of that time and the khagans who were responsible for the gathering of the Turkish peoples and also for the establishment of Khaganate. Three monuments are named after the three most successful and significant khagans. The lettering of these inscriptions is reminiscent of Germanic runes, and in addition to the more commonly known name, the Gokturk or Kokturk script (named after the Gokturks or Kokturks), it is often referred to as the Turkish runes.
\end{abstract}

Key words: Orkhon monuments, Orkhon inscriptions, Gokturks, Kokturks, Turks, the Turkish language 